and the Shakespearean character of that name become inextricably entangled. Even in 1647 Buck $^{1}$ was quoting earlier authorities denying the existence of any skeletal deformity other than shortness of stature. More's description of the "left shoulder being much higher than the right": is not confirmed by the portrait in the National Portrait Gallery, which appears to show the right shoulder as the higher one -as Professor Rhodes reports.

Although Shakespeare's account is not to be trusted entirely, an examination of the Henry VI trilogy and Richard III suggests that an additional possibility exists-that Richard of Gloucester was a coeliac.

His condition was probably familial. Anne's curse (Richard III, I, ii, 21, 22) suggests that his son, his "heir to his unhappiness" (I, ii, 25), had the same condition; she used almost precisely the same terms as those by which Richard was described (I, iii, 228; I, i, 20, 21) and indeed we know that the young Prince Edward was delicate and died in childhood."

Richard as a child showed the cocliac's failure to thrive: "He was the wretched'st thing when he was yourig, So long a-growing and so leisurely" (II, iv, $18,19)$ and had the characteristic naughtiness "Tetchy and wayward was thy infancy" (IV, iv, 168). He was that "bottled spider" (I, iii, 242; IV, iv, 81)-that is, a bloated spider, a creature with distended abdomen and skinny limbs. The limb-wasting was used by Richard, in the play, to dispose of Hastings by falsely accusing him of witchcraft (III, iv, 69, 70).

Discussion of bowel habit would present any dramatist with almost insuperable difficulties. Shakespeare goes out of his way to draw our attention to his use of double meanings (III, i, 82) He refers to Richard repeatedly as "foul." Taking advantage of Gloucester's device, the white boar, he refers to him as "foul swine" (V, ii, 10)-th "smelly pig" interpretation is difficult to avoid. In all his works Shakespeare uses "indigested" on only two occasions; both occur in Henry VI (Pt II $\mathrm{V}, \mathrm{i}, 157 ;$ Pt III: V, vi, 51) and both refer to Richard. The Part II reference comes in a bitte exchange between Clifford, Richard, and the Duke of York (Richard's father)

Clifford (to Richard): "Hence heap of wrath,

foul indigested lump,

As crooked in thy manners as thy shape!"

Duke of York: "Nay, we shall heat you thoroughly anon."

On the face of it, York's enigmatic retort appears to be inappropriate until it is realised that in the ancient view digestion was effected by heat and the "coeliac passion" brought about by the lack of it. ${ }^{3}$ By referring to Richard as "indigested" Clifford implies that he lacks body heat-hence York's angry response.

Coeliac disease was known, by name, at the time of writing of Richard III. Although $\mathrm{Gee}^{4}$ is usually recognised as being the first to describe th "coeliac affection," it was Aretaeus the Cappadocian who first described the disorder in the firs century $\mathrm{AD}$, giving it its present name. ${ }^{35}$ Reference to the "coeliac passion," and in many cases full descriptions, have occurred in several seventeenth and eighteenth century medical textbooks. ${ }^{35-10}$ Gee recognised it as the AngloSaxon "wambecothe" or belly sickness; he included in his account a couplet found ${ }^{6}$ to be the work of Francis Quarles (1592-1644), suggesting that the condition occurred "often." A Latin translation of Aretaeus appeared in $1552^{11}$; in 1580 , 12 years before the writing of Richard III, Pisonis ${ }^{12}$ included in his book a chapter on "De lientaria et coeliaca." The coeliac passion was sometimes linked" with lientaria, a "flyxe of the wombe [that is, belly] wythout passynge of meete and drynke withoute dygestyon."13

As with all things relating to Richard, it is difficult to find independent evidence. He was certainly small. He preferred the outdoors ${ }^{2}-$ perhaps he felt easier in the fresh air, where odour would be less apparent. His portrait in the National Portrait Gallery is not helpful except, perhaps, to show the inverted triangular face supposed to be typical of the adult male with idiopathic steatorrhoea ${ }^{14}$ and to suggest koilonychia in the right third finger.

On the basis of coeliac disease the skeletal deformity, if indeed it existed, was perhaps the result of either osteoporosis of the spine or the effect of osteomalacia on the scapula.

\section{GORDON DALE}

University Department of Clinical Biochemistry, Royal Victoria Infirmary

' Buck, G, The History of the Life and Reigne of Richard

the Third. London, 1647.
${ }^{2}$ Kendall, P M, Richard the Third. London, Allen and Unwin, 1955.

James, R, Medicinal Dictionary. London, Osborne$$
17 \text {. }
$$

Parr, B, London Medical Dicrionary. London, 1809.

Dowd, B, and Walker-Smith, J, British Medical fournal, 1974, 2, 45

Buchan, W, Domestic Medicine. London, 1792

Blankaart, S, Lexicon Medicum Renovatum. Amsterdam, Luchtmans, 1702.

"Chandler, J, Van Helmont's Oriatrike. London, 1662

an Helmont,

Bernard, J P, et al, Bayle's Dictionary. London, 1735. 12 Pisonis, N, Medici Lotharingide Cognoscendis Curandis, 1580

Oxford English Dictionary Oxford, Clarendon Press, 1933.

Cooke, W T, Peeney, A L P, and Hawkins, C F,
Quarterly fournal of Medicine, 1953, 22, 59.

\section{Hazards and benefits of cimetidine therapy}

SIR,-It was with some interest that I read the letter from Mr D J Ellis and others reporting perforation of a chronic duodenal ulcer during treatment with cimetidine (10 December, p 1538). In a peripheral surgical unit such as this, somewhat distant from the large district hospital, cimetidine would appear to have considerable attractions. May I illustrate the two ends of the spectrum with two cases?

Case 1-A hypertensive 56-year-old man with a fairly dense but recovering right hemiparesis was investigated in March 1977. He presented with symptoms of constipation and vomiting, the latter of a recurrent nature. He was known to have a chronic duodenal ulcer with slight delay in stomach emptying. He had responded successfully to cimetidine therapy. Sigmoidoscopy and bariumenema examination were within normal limits. He was discharged and surgery proposed if he did not settle on the drug regimen, which was continued. In May 1977 the patient was admitted with the classical clinical and radiological signs of a perforated peptic ulcer. He had been well up to the time of admission. At operation a large perforation of an anterior duodenal ulcer was found. After local closure, peritoneal toilet, and a definitive vagotomy and drainage operation he made a satisfactory recovery.

Case 2-In November 1976 a 78 -year-old man was admitted with retention of urine and intestinal obstruction. The former was thought to be secondary to Libraxin (chlordiazepoxide and clidinium) therapy; he was known to have a chronic duodenal ulcer. His bladder tone recovered but his small-intestinal obstruction did not settle and required decompression and resection of a constriction ring. At operation a chronic duodenal ulcer was confirmed. Twenty-four hours after surgery the patient had a large haematemesis and melaena. He was given cimetidine and transfused. His bleeding ceased and he subsequently made an uneventful recovery, being discharged 10 days later.

The two patients demonstrate the hazards and benefits of cimetidine therapy. The apparent success of the drug in case 1 although penetrating ulceration was progressing is disquieting. Case 2 shows the successful emer- gency treatment with cimetidine of a complicated peptic ulcer in a debilitated patient. Especially is this important in the poor-risk, immediate postoperative patient when a peptic ulcer is a known fact and further surgery is prohibited.

JoHN R BaLL

Dr Mackinnon Memorial Hospital Broadford, Isle of Skye

\section{Cimetidine and haemodialysis}

SIR,-We were interested to read the article by Dr Ciaran C Docherty and others (17 December, p 1506) showing the benefits of cimetidine treatment in patients with duodenal ulcer undergoing haemodialysis. While we agree with the general conclusions of the paper, we should like to comment on the statement that food-stimulated serum gastrin levels were increased significantly after cimetidine treatment. From the data presented it would appear that there was a significant difference in fasting gastrin levels between the two groups, presumably related to reduced acid secretion and loss of negative feedback. Thus, to conclude that after food stimulation in patients receiving cimetidine there was a significantly increased gastrin release is in our view erroneous unless substantiated by a difference in integrated gastrin response.

\section{N I RAMUS}

\section{N J MCC MORTENSEN}

Department of Surgery,
Southmead General Hospital, Bristol

\section{Complicated polymyalgia}

SIR,-We were interested to read the important short paper by Dr E C Huskisson and others on complicated polymyalgia (3 December, p 1459). To support their view of an association of polymyalgia rheumatica or temporal arteritis with malignancy, we briefly present the following three cases.

Case 1-This 67-year-old woman presented four and a half years ago with severe headaches. Temporal arteries were tender and biopsy was positive for temporal arteritis. The erythrocyte sedimentation rate (ESR) was $70 \mathrm{~mm}$ in the first hour. She was treated with $30 \mathrm{mg}$ prednisolone daily. When attempts were made to reduce her steroid dose she developed pain and stiffness in her arms, shoulders, and thighs. Eighteen months after the onset of her headac'ies she developed haemoptysis and radiographs showed carcinoma of the bronchus. She had a left upper lobectomy. Subsequently her limb girdle pain and stiffness settled and her steroid dose was easily reduced. She had no further history of headaches and she is now on $2.5 \mathrm{mg}$ prednisolone daily.

Case 2-This 70-year-old woman presented with polymyalgia rheumatica. Her ESR was $68 \mathrm{~mm}$ in the first hour. She was started on steroids and initially made a good improvement. Her symptoms began to reappear despite steroid treatment. Four months later it was noticed that she had an iron deficiency anaemia and positive occult bloods. A barium enema examination showed a carcinoma of the caecum, which was successfully removed at operation. Subsequently her shoulder and pelvic girdle symptoms disappeared and her steroids were tailed off completely. She remained asymptomatic. Subsequent bone scan was negative.

Case 3-This 78-year-old man developed polymyalgia rheumatica 11 months ago. ESR was $60 \mathrm{~mm}$ in the first hour. He was started on steroids. Initially a good improvement was made but symptoms recurred. Four months later he complained of haemoptysis and radiography and fibreoptic bronchoscopy showed carcinoma of the 